\title{
TINJAUAN KRITIS TERHADAP IMPLEMENTASI ISO 9000
}

\author{
Nursya'bani Purnama \\ Fakultas Ekonomi Universitas Islam Indonesia
}

\begin{abstract}
Abstrak
ISO 9000 telah diterima secara luas sebagai acuan sistem manajemen kualitas dan penjaminan kualitas. Perusahaan-perusahaan yang memperoleh sertifikasi ISO dari tahun ke ke tahun mengalami pertumbuhan yang pesat. Dengan implementasi dan memperoleh sertifikasi ISO 9000, banyak perusahaan di dunia memperoleh peningkatan kinerja. Meskipun demikian, implementasi ISO 9000 juga dihadapkan pada sejumlah hambatan.

Implementasi ISO 9000 seringkali dikaitkan dengan Total Quality Management (TQM). Banyak pihak yang menyatakan bahwa implementasi ISO 9000 sebagai langkah awal implementasi TQM. Namun antara ISO 9000 dengan TQM memiliki perbedaan yang mendasar. Oleh karena itu ISO 9000: 2000 sebagai revisi terhadap ISO 9000: 1994 didasarkan pada semangat total quality dan dipahami sebagai upaya lebih mendekatkan ISO 9000 dengan TQM.
\end{abstract}

Kata kunci: ISO 9000, ISO 9001, ISO 9002, ISO 9003, ISO 9004, Total Quality Management

\section{PENDAHULUAN}

Ketika kualitas menjadi fokus utama bisnis di dunia, berbagai organisasi mengembangkan standar dan pedoman sistem manajemen kualitas. Sebagai akibatnya, terminologi manajemen kualitas, pengendalian kualitas, sistem kualitas, dan penjaminan kualitas yang diperoleh berbeda, dan kadang-kadang menimbulkan pertentangan antar negara, antar industri dalam satu negara, bahkan antar perusahaan dalam satu industri. Pada saat negara-negara Eropa membentuk Perjanjian Perdagangan Bebas Eropa (the European Free Trade Area), manajemen kualitas menjadi sasaran stategik kunci. Untuk memenuhi standardisasi persyaratan kualitas negara-negara Eropa dan pasar bersama, serta untuk pengerjaan bisnis, agen khusus untuk standardisasi, the International Organization for Standardization mengeluarkan seri standar ISO 9000 . Standar ISO 9000 diciptakan untuk memenuhi lima tujuan, yaitu: 1) mencapai, mempertahankan, dan menemukan perbaikan kualitas produk secara terus menerus dan berkesinambungan (termasuk layanan) dalam hubungannya dengan persyaratan, 2) meningkatkan kualitas operasi secara terus menerus untuk memenuhi harapan konsumen dan pemilik perusahaan, 3) memberikan kepercayaan kepada manajemen internal dan pekerja bahwa persyaratan kualitas telah terpenuhi dan perbaikan telah dilakukan, 4) memberikan kepercayaan kepada konsumen dan pemilik bahwa persyaratan kualitas telah terpenuhi dalam produk yang dikirimkan, 5) memberikan kepercayaan bahwa persyaratan sistem kualitas telah terpenuhi.

Saat ini standar seri ISO 9000 diterima secara luas sebagai standar minimum sistem kualitas perusahaan. Pada dasarnya, standar seri ISO 9000 
merupakan rangkaian standar sistem kualitas yang menggambarkan praktek-praktek kualitas yang baik, namun tanpa menjelaskan bagaimana suatu perusahaan harus mencapainya. Standar ISO 9000 menyediakan persyaratan sistem manajemen kualitas bagi perusahaan, namun upaya untuk memenuhi standar tersebut tidak diatur di dalam ISO 9000. Artinya organisasi sendiri yang harus berupaya mencapai ketentuan yang dipersyaratkan dalam standar tersebut.

Penggunaan standar ISO 9000 di negara-negara di dunia dari waktu ke waktu pertumbuhannya semakin pesat. Hal ini dibuktikan dengan semakin banyaknya perusahaan yang mengadopsi filosofi ISO 9000 dan memperoleh sertifikasi ISO 9000. Jepang merupakan negara yang pertumbuhannya paling pesat, rata-rata perusahaan Jepang yang memperoleh sertifikasi ISO 9000 tumbuh $115,6 \%$ per tahun, diikuti Jerman 78\%, Kanada 77\%, USA 72,8\%, India, 72\%, Malaysia 63\%, Perancis $53,2 \%$, Singapura 53\%, Australia dan Selandia Baru 41,6\% (Chow-Chua, et al., 2002).

ISO 9000 seolah telah menjadi madu yang menyehatkan bagi perusahaan. Upaya mendekatkan konsumen dengan perusahaan bisa dicapai dengan implementasi persyaratan ISO 9000. Saat ini implementasi ISO 9000 telah menjadi keharusan bagi perusahaan di dunia. Sama halnya ketika total quality management (TQM) memberikan kontribusi besar bagi perusahaan, banyak perusahaan berlomba-lomba mengadopsi dan mengimplementasikan filosofi TQM. ISO 9000 dan TQM merupakan dua hal yang dinilai banyak pihak sebagai saudara kandung. Keduanya memiliki hubungan yang sangat dekat. Tidak sedikit orang yang berpandangan bahwa ketika perusahaan mengimplementasikan ISO 9000 berarti juga telah mengimpelementasikan TQM, begitu juga sebaliknya. Pandangan tersebut tidak sepenuhnya benar, namun juga tidak bisa dikatakan salah. Untuk menjawab kontroversi pandangan itu, tulisan ini akan mengungkapkan tinjauan impelementasi ISO 9000 , mulai dari persyaratan, manfaat, dan hambatan, serta mencoba memberikan perbandingan antara ISO 9000 dengan TQM.

\section{PENGERTIAN DAN SEJARAH SINGKAT ISO 9000}

ISO 9000 adalah nomor acuan pada suatu seri standar internasional yang menjabarkan kriteria sistem manajemen kualitas. Pada standar tersebut terdapat persyaratan mendasar bagi organisasi yang berkeinginan untuk menerapkan sistem manajemen kualitas. ISO 9000 mendefinisikan standar sistem kualitas, didasarkan premis bahwa karakteristik tertentu dari praktek-praktek manajemen kualitas dapat distandarkan dan didisain dengan baik, diterapkan dengan baik, pengelolaan sistem kualitas secara hati-hati akan memberikan kepercayaan bahwa output akan memenuhi persyaratan dan harapan konsumen.

Standar ISO 9000 diperkenalkan tahun 1987 oleh the International Organisation for Standardisation di Jenewa, Swis. Standar ISO 9000 didasarkan pada konsep bahwa karakteristik minimum tertentu sistem manajemen kualitas dapat distandarisasi, sistem manajemen kualitas memberikan manfaat kepada pemasok 
dan pelanggan, dan berfokus pada proses. ISO 9000 juga memuat prosedur pengendalian manajemen, yang di dalamnya termasuk pendokumentasian proses disain, produksi dan distribusi untuk menghasilkan produk dan layanan yang sesuai dengan kebutuhan pelanggan.

\section{STRUKTUR STANDAR ISO 9000}

\section{Seri ISO 9000}

Standar manajemen kualitas dan penjaminan kualitas - Panduan untuk pemilihan dan penggunaan standar. Standar ini bisa digunakan oleh perusahaanperusahaan yang perlu memberikan jaminan kepada pelanggan bahwa persyaratan tertentu yang diminta telah terpenuhi semuanya, mulai dari perancangan (disain) sampai pelayanan.

- ISO 9000-1 merupakan standar manajemen kualits dan penjaminan kualitas yang memberikan panduan untuk pemilihan dan pemakaian keluarga ISO 9000 atas manajemen kualitas dan penjaminan kualitas.

- ISO 9000-2 merupakan standar manajemen kualitas dan penjaminan kualitas yang memberikan panduan generik bagi aplikasi ISO 9001, ISO 9002, dan ISO 9003. ISO 9000-2 juga memuat kIAusul-klausul yang termasuk dalam ISO 9001, ISO 9002, dan ISO 9003 serta panduan untuk setiap klausul.

- ISO 9000-3 merupakan standar manajemen kualitas dan penjaminan kualitas yang memberikan panduan untuk aplikasi ISO 9001 dalam mengembangkan, memasok, dan memelihara perangkat lunak (software).

- ISO 9000-4 merupakan standar manajemen kualitas dan penjaminan kualitas yang memberikan panduan bagi keandalan manajemen kualitas yang menyangkut perencanaan, pengorganisasian, pengarahan, dan pengendalian sumber daya untuk memproduksi produk atau layanan yang dapat diandalkan.

\section{ISO 9001}

Model sistem kualitas - Model untuk penjaminan kualitas dalam organisasi menyangkut proses perancangan (disain), pengembangan, produksi, instalasi dan pelayanan. Standar ini merupakan standar terlengkap dan dituntut untuk bisa diaplikasikan dalam situasi kontraktual. Standar ini cocok digunakan khususnya oleh perusahaan manufaktur yang merancang dan membuat produk sendiri.

\section{ISO 9002}

Model sistem kualitas - Model untuk penjaminan kualitas organisasi menyangkut proses produksi dan instalasi, tidak termasuk perancangan (disain) dan pengembangan. Setelah perancangan (disain) dan spesifikasi ditentukan, baik secara internal atau dari pelanggan, model ini digunakan untuk memperlihatkan kemampuan dalam produksi dan instalasi. Standar ini cocok digunakan oleh perusahaan yang menghasilkan produk yang spesifikasinya ditentukan pihak lain. 
ISO 9003

Model sistem kualitas - Model untuk penjaminan kualitas dalam organisasi menyangkut proses inspeksi akhir dan pengujian kesesuain produk dengan persyaratan yang ditetapkan. Model ini digunakan untuk memperlihatkan kemampuan inspeksi dan pengujian jika produknya dipasok oleh suatu perusahaan pemanufaktur. Standar ini khusus digunakan oleh badan-badan seperti laboratorium pengujian, pusat kalibrasi, dan distribusi peralatan yang melakukan pemeriksaaan dan pengujian produk-produk yang dipasok.

Tabel 1. Perbandingan Persyaratan ISO 9001, 9002, 9003

\begin{tabular}{|l|l|c|c|c|}
\hline No & \multicolumn{1}{|c|}{ Persyaratan } & ISO 9001 & ISO 9002 & ISO 9003 \\
\hline 1 & Tanggung jawab manajemen & $\sqrt{ }$ & $\sqrt{ }$ & $\sqrt{ }$ \\
\hline 2 & Sistem kualitas & $\sqrt{ }$ & $\sqrt{ }$ & $\sqrt{ }$ \\
\hline 3 & Tinjauan kontrak & $\sqrt{ }$ & $\sqrt{ }$ & $\sqrt{ }$ \\
\hline 4 & Pengendalian disain & $\sqrt{ }$ & & \\
\hline 5 & Pengendalian dokumen dan data & $\sqrt{ }$ & $\sqrt{ }$ \\
\hline 6 & Pembelian & $\sqrt{ }$ & $\sqrt{ }$ & \\
\hline 7 & Pengendalian produk yang dipasok oleh pelanggan & $\sqrt{ }$ & $\sqrt{ }$ & $\sqrt{ }$ \\
\hline 8 & Identifikasi dan kemampuan penelusuran produk & $\sqrt{ }$ & $\sqrt{ }$ & $\sqrt{ }$ \\
\hline 9 & Pengendalian proses & $\sqrt{ }$ & $\sqrt{ }$ & \\
\hline 10 & Inspeksi dan pengujian & $\sqrt{ }$ & $\sqrt{ }$ & $\sqrt{ }$ \\
\hline 11 & Inspeksi, pengukuran, dan peralatan pengujian & $\sqrt{ }$ & $\sqrt{ }$ & $\sqrt{ }$ \\
\hline 12 & Inspeksi dan status pengujian & $\sqrt{ }$ & $\sqrt{ }$ & $\sqrt{ }$ \\
\hline 13 & Pengendalian terhadap produk yang tidak sesuai & $\sqrt{ }$ & $\sqrt{ }$ & $\sqrt{ }$ \\
\hline 14 & Tindakan koreksi & $\sqrt{ }$ & $\sqrt{ }$ & $\sqrt{ }$ \\
\hline 15 & Penanganan, penyimpanan, pengepakan, dan pengiriman & $\sqrt{ }$ & $\sqrt{ }$ & $\sqrt{ }$ \\
\hline 16 & Pengendalian Catatan kualitas & $\sqrt{ }$ & $\sqrt{ }$ & $\sqrt{ }$ \\
\hline 17 & Audit kualitas internal & $\sqrt{ }$ & $\sqrt{ }$ & \\
\hline 18 & Pelatihan & $\sqrt{ }$ & $\sqrt{ }$ & $\sqrt{ }$ \\
\hline 19 & Pelayanan & $\sqrt{ }$ & $\sqrt{ }$ & $\sqrt{ }$ \\
\hline 20 & Teknik-teknik statistik & $\sqrt{ }$ & $\sqrt{ }$ & \\
\hline
\end{tabular}

Sumber: Chatab (1996)

\section{ISO 9004}

Elemen-elemen manajemen kualitas dan sistem kualitas - Panduan yang berkaitan dengan organisasi. ISO 9004 tidak dimaksudkan untuk kepentingan kontraktual, tetapi merupakan suatu dokumen untuk kepentingan internal organisasi.

- ISO 9004-1 memberikan panduan terhadap elemen manajemen kualitas dan sistem kualitas. Elemen sistem kualitas ini cocok dan berguna dalam pengembangan dan implementasi secara menyeluruh sistem kualitas internal dengan titik pandang memastikan kepuasan pelanggan, karena aktivitas di dalamnya mencakup seluruh fase siklus kehidupan produk atau layanan (jasa). Setiap organisasi tergantung pada berbagai factor yang dihadapi, seperti pasar yang dilayani, sifat produk, proses produk, pelanggan dan kebutuhan pelanggan. 
Oleh karena itu, untuk penerapannya pada organisasi yang lebih spesifik disediakan bagian berikutnya dari seri ISO 9004, yaitu:

- ISO 9004-2 Panduan bagi jasa

- ISO 9004-3 Panduan bagi bahan yang diproses

- ISO 9004-4 Panduan bagi peningkatan kualitas

- $\quad$ ISO 9004-5 Panduan bagi perencanaan penjaminan kualitas

- ISO 9004-6 Panduan untuk penjaminan kualitas untuk manajemen proyek

- $\quad$ ISO 9004-7 Panduan untuk manajemenkonfigurasi

- $\quad$ ISO 9004-8 Panduan untuk prinsip-prinsip kualitas dan penerapannya dalam praktek manajemen

\section{MANFAAT SERTIFIKASI ISO 9000}

Banyak perusahaan yang mengakui bahwa dengan menerapkan ISO 9000, mereka telah memperoleh peningkatan kinerja. Di samping itu, penerapan ISO 9000 telah menghantarkan banyak perusahaan memperoleh penghargaan manajemen kualitas internasional. Kantner (1997) menyebutkan bahwa banyak perusahaan memiliki pengalaman meningkatkan penjualan setelah memperoleh sertifikasi ISO. Calingo (1995) menyatakan bahwa dengan ISO 9000 perusahaan dapat mencapai sistem kualitas yang lebih baik, kepuasan konsumen, kekuatan bersaing, dan pengurangan masalah kualitas. Haversjo (2000) melaporkan bahwa dengan sertifikasi ISO 9000 perusahaan-perusahaan memperoleh rates of return yang lebih tinggi dibanding perusahaan yang belum memperoleh sertifikasi.

Sedangkan hasil penelitian yang dilakukan Lai (1995) dalam Ek dan Cheng (1995) menunjukkan beberapa manfaat yang diperoleh perusahaan setelah memperoleh sertifikasi ISO 9000, yaitu:

1. Menjamin pasar baru

- Menjamin peluang ekspor ke pasar eropa

- Menjamin peluang ekspor ke pasar-pasar lain

2. Memperbaiki posisi persaingan

3. Tekanan dan kepuasan konsumen

- Memperbaiki keyakinan konsumen

- Kepuasan konsumen terpenuhi

- Kepuasan konsumen meningkat

4. Manfaat praktis

- Memperbaiki sistem kualitas yang telah ada

- Pendokumentasian kualitas yang telah ada

- Meningkatkan kesadaran kualitas

- Mengurangi masalah-masalah kualitas

- Memperbaiki komunikasi antar pekerja

- Tercapainya kerja tim dan kerjasama antar pekerja yang lebih baik

- Memperbaiki proses 
- Mengurangi pekerjaan ulang dan pemborosan

- Membantu pencapaian TQM

Hasil penelitian di atas diperkuat oleh peneliti-peneliti lain, seperti yang telah dirangkum oleh Chow-Chua, et al. (2002). Informasi lebih lengkap tentang hasil-hasil penelitian manfaat sertifikasi ISO 9000 disajikan pada tabel 2.

Tabel 2. Manfaat Sertifikasi ISO 9000

\begin{tabular}{|c|c|}
\hline Manfaat & Sumber Referensi \\
\hline Citra (image) perusahaan lebih baik. & $\begin{array}{l}\text { Goetch dan Davis (1998), Johnson (1997), Tsiotras dan Gotzamani } \\
\text { (1996) Vloeberghs dan Bellens (1996). }\end{array}$ \\
\hline Kesadaran terhadap kualitas lebih besar. & $\begin{array}{l}\text { Brown dan Van der Wiele (1995a,b), Brown, et al. (1998), Dale } \\
\text { (1994), Dick (2000), Goetch dan Davis (1998), Quazi dan Padibjo } \\
\text { (1998), Tsoitras dan Gotzamani (1996). }\end{array}$ \\
\hline Prosedur dokumentasi lebih baik. & $\begin{array}{l}\text { Goetch dan Davis (1998), Jones, et al. (1997), McLachlan (1996), } \\
\text { Santos dan Escanciano (2002), Tsiotras dan Gotzamani (1996). }\end{array}$ \\
\hline Instruksi dan prosedur kerja lebih jelas. & Santos dan Escanciano (2002), Tsiotras dan Gotzamani (1996). \\
\hline Pertanggungjawaban pekerjaan lebih jelas. & McLachan (1996), Santos dan Escanciano (2002). \\
\hline $\begin{array}{l}\text { Menghilangkan kelebihan pekerjaan/mengu- } \\
\text { rangi pekerjaan yang tidak penting. }\end{array}$ & Lloyd's Register Quality Assurance Ltd (1994), McLachan (1996). \\
\hline $\begin{array}{l}\text { Memberi peluang akses, pelacakan, dan } \\
\text { pemeriksaan prosedur kerja yang mudah. }\end{array}$ & $\begin{array}{l}\text { Dale (1994), Dick (2000), Lloyd's Register Quality Assurance Ltd } \\
\text { (1994). }\end{array}$ \\
\hline Layanan konsumen lebih baik. & $\begin{array}{l}\text { Brown dan Van der Wiele (1995a, b), Brown, et al. (1998), Jones, } \\
\text { et al. (1997), McLachlan (1996), Raynor dan Porter (1991). }\end{array}$ \\
\hline Mengurangi pemborosan dan inefisiensi. & $\begin{array}{l}\text { Brown, et al. (1998), Dale (1994), Dick (2000), Garvin (1998), } \\
\text { Gotzamani dan Tsiotras (2002), Lee (1998), Mo dan Chan (1997), } \\
\text { Raynor dan Porter (1991). }\end{array}$ \\
\hline Meningkatkan kepuasan konsumen. & $\begin{array}{l}\text { Brown dan Van der Wiele (1995a, b), Dale (1994), Lee (1998), } \\
\text { McLachlan (1996), Mo dan Chan (1997), Morgan dan Pierce (1992), } \\
\text { Gotzamani dan Tsiotras (2002), Quazi and Padibjo (1998), Raynor dan } \\
\text { Porter (1991). }\end{array}$ \\
\hline Keunggulan bersaing lebih besar. & $\begin{array}{l}\text { Brown dan Van der Wiele (1995a, b), Corrigan (1994), Dick (2000), } \\
\text { Gotzamani dan Tsiotras (2002), McLachlan (1996), Quazi dan } \\
\text { Padibjo (1998). }\end{array}$ \\
\hline Membantu peningkatan yang kontinyu. & Brocka dan Borcka (1994), Dick (2000), and McLachan (1996). \\
\hline Daya ingat/retensi staf lebih besar. & $\begin{array}{l}\text { Brown, et al. (1998), Gotzamani dan Tsiotras (2002), McLachan } \\
\text { (1996), Mo dan Chan (1997). }\end{array}$ \\
\hline Meningkatkan profitabilitas. & $\begin{array}{l}\text { Dick (2000), Gotzamani dan Tsiotras (2002), Haversjo (2000), } \\
\text { Jones, et al. (1997), Lee (1998), Mo dan Chan (1997), Scotto } \\
\text { (1996), Santos dan Escanciano (2002). }\end{array}$ \\
\hline Memperbesar pangsa pasar. & $\begin{array}{l}\text { Brown, et al. (1998), Dick (2000), Lloyd's Register Quality } \\
\text { Assurance Ltd (1994), John, et al. (1997), McLachlan (1996) } \\
\text { Santos dan Escanciano (2002). }\end{array}$ \\
\hline Peluang ekspor lebih besar. & Brown, et al. (1998), Dick (2000), Gotzamani dan Tsiotras (2002). \\
\hline Ekspansi ke pasar internasional. & Brown, at al. (1998) and Lloyd's Register Quality Assurance Ltd (1994). \\
\hline
\end{tabular}

Sumber: Chow-Chua, et al (2002) 
Mengacu hasil penelitian Ek dan Cheng (1995) dan rangkuman hasil-hasil penelitian yang disampaikan Chow-Chua, et al. (2002) semakin memberikan keyakinan bahwa sertifikasi ISO memberikan manfaat besar bagi perusahaan dalam banyak hal. Manfaat-manfaat tersebut bisa dikelompokkan ke dalam manfaat yang bersifat internal dan ekternal.

\section{Manfaat Internal}

Manfaat internal merupakan manfaat yang dirasakan dan bisa dilihat di dalam lingkup internal organisasi, meliputi:

口 Kesadaran terhadap kualitas semakin besar

a Prosedur dokumentasi lebih baik

- Instruksi dan prosedur kerja lebih jelas

- Pertanggungjawaban pekerjaan semakin jelas

- Menghilangkan kelebihan pekerjaan/mengurangi pekerjaan yang tidak penting

- Memberi peluang akses, pelacakan, dan pemeriksaan prosedur kerja yang mudah

a Mengurangi pemborosan dan inefisiensi

口 Membantu perbaikan yang kontinyu

口 Daya ingat/retensi staf lebih besar

a Meningkatkan profitabilitas

\section{Manfaat Eksternal}

Manfaat eksternal merupakan manfaat yang berkaitan dengan kondisi factor eksternal, meliputi:

- Citra (image) perusahaan lebih baik

- Layanan konsumen lebih baik

- Kepuasan konsumen meningkat

口 Keunggulan bersaing lebih besar

- Memperbesar pangsa pasar

- Peluang ekspor lebih besar

- Ekspansi ke pasar internasional

Hasil-hasil temuan manfaat ISO 9000 di atas, mendorong Chow-cua, et al (2002) untuk membuktikan manfaat sertifikasi ISO 9000 bagi perusahaan, dengan melakukan penelitian terhadap 146 perusahaan di Singapura. Seperti halnya peneliti terdahulu, mereka juga menggunakan instrumen penelitian berupa kuisioner dengan skor jawaban menggunakan skala Likert 1 - 5. Hasil penelitian menyebutkan bahwa dalam beberapa hal perusahaan-perusahaan di Singapura menyatakan memperoleh manfaat dari sertifikasi ISO 9000. Manfaat terbesar dari perusahaan yang memperoleh sertifikasi ISO 9000 adalah prosedur dokumen yang lebih baik $(4,29)$, instruksi atau prosedur kerja lebih jelas $(4,14)$, kemampuan akses, pelacakan, dan audit prosedur kerja yang mudah $(4,11)$. Namun hasil penelitian Chow-Chua, et al. 
(2002) juga menunjukkan hal yang berbeda dengan hasil-hasil penelitian terdahulu. Beberapa faktor dinilai bukan sebagai manfaat dari sertifikasi ISO 9000, yaitu: ekspansi ke pasar internasional, meningkatkan penjualan (pangsa pasar), meningkatkan profitabilitas, peluang ekspor lebih besar, daya ingat/retensi staf lebih besar.

\section{HAMBATAN IMPLEMENTASI ISO 9000}

Tabel 3. Hambatan Implementasi ISO 9000

\begin{tabular}{|c|c|c|}
\hline No. & Hambatan & $\begin{array}{l}\text { Perusahaan } \\
\text { terdaftar (\%) }\end{array}$ \\
\hline \multicolumn{3}{|c|}{ Selama Implementasi } \\
\hline 1. & Gagal menyediakan dokumen dan data pengendalian yang memadai. & 20 \\
\hline 2. & Gagal dalam mendefinisikan tanggungjawab dan wewenang individu. & 51.4 \\
\hline 3. & Kalibrasi alat dan ukuran. & 17.1 \\
\hline 4. & Lemah dalam praktek penerimaan bahan baku yang masuk. & 22.9 \\
\hline 5. & Gagal dalam mengikuti prosedur pengendalian proses yang ditulis. & 8.6 \\
\hline 6. & Pengendalian pemasok tidak sempurna. & 11.4 \\
\hline 7. & Pengendalian produk yang tidak sesuai tidak memadai. & 17.1 \\
\hline 8. & Pelatihan yang tidak memadai. & 14.3 \\
\hline 9. & Dokumentasi terlambat. & 11.4 \\
\hline 10. & $\begin{array}{l}\text { Tinjauan manajemen secara periodic terhadap elemen sistem kualitas } \\
\text { tidak dilaksanakan atau catatan tinjauan tidak memadai. }\end{array}$ & 14.3 \\
\hline 11. & $\begin{array}{l}\text { Tinjauan kontrak tidak diadakan atau perubahan ontrak tidak direfleksikan } \\
\text { dalam lembara kerja. }\end{array}$ & 11.4 \\
\hline 12. & Interpretasi yang salah terhadap persyaratan ISO. & 17.1 \\
\hline \multicolumn{3}{|c|}{ Setelah Implementasi } \\
\hline 1. & $\begin{array}{l}\text { Prosedur pengendalian dokumen tidak bisa dipakai dan tidak bisa diker- } \\
\text { jakan dan sebagai hasilnya tidak bisa diikuti. }\end{array}$ & 22.9 \\
\hline 2. & $\begin{array}{l}\text { Gagal membawa tinjauan manajemen terhadap sistem kualitas mencapai } \\
\text { efektivitas system. }\end{array}$ & 37.1 \\
\hline 3. & Gagal dalam mengikuti prosedur yang didokumentasi. & 14.3 \\
\hline 4. & $\begin{array}{l}\text { Gagal memiliki dokumen dengan level lebih rendah seperti prosedur dan } \\
\text { instruksi kerja di bawah pengendalian. }\end{array}$ & 11.4 \\
\hline 5. & Kurang umpan balik menyangkut proses. & 20 \\
\hline 6. & Gagal dalam memonitor dan mempertahankan kinerja auditor. & 8.6 \\
\hline 7. & $\begin{array}{l}\text { Gagal dalam program audit untuk menyediakan manajemen dan peme- } \\
\text { nuhan kebijakan dan prosedur kualitas. }\end{array}$ & 5.7 \\
\hline
\end{tabular}

Sumber : Chow-Chua, et al. (2002)

Seperti halnya penerapan sistem kualitas yang lain, penerapan ISO 9000 juga menghadapi beberapa hambatan, baik pada saat proses memperoleh sertifikasi ISO 900 maupun setelah memperoleh sertifikasi ISO 9000. Hambatan yang dihadapi dalam ISO 9000 dapat diidentifikasi selama implementasi dan sesudah memperoleh sertifikasi ISO 9000. Hambatan selama implementasi terjadi kemungkinan karena perusahaan harus melakukan adaptasi atau perubahan-perubahan sesuai persya- 
ratan yang ditetapkan ISO 9000. Sedangkan hambatan yang dihadapi setelah mendapatkan sertifikasi ISO terjadi karena perusahaan seringkali merasa bahwa sudah tidak ada lagi control langsung yang dihadapi. Hasil penelitian Chow-cua, et al (2002) tentang hambatan selama implementasi ISO 9000 dan sesudah memperoleh sertifikasi disajikan pada Tabel 3. Hambatan terbesar selama implementasi ISO 9000 adalah organisasi gagal dalam mendefinsikan pertanggungjawaban dan wewenang personal $(51,4 \%)$, sedangkan hambatan terbesar setelah memperoleh sertifikasi ISO 9000 adalah organisasi gagal membawa tinjauan manajemen terhadap sistem kualitas untuk mencapai efektivitas sistem $(37,1 \%)$.

\section{PERBANDINGAN ISO 9000 DENGAN TOTAL QUALITY MANAGEMENT (TQM)}

ISO 9000 dengan TQM merupakan dua hal yang memiliki keterkaitan erat. Kebanyakan perusahaan yang menerapkan ISO 9000 pada saat yang bersamaan juga mengadopsi prinsip-prinsip TQM. Banyak ahli manajemen kualitas yang berpendapat bahwa penerapan ISO 9000 merupakan langkah awal penerapan TQM. Pandangan ini kemudian dikenal sebagai pandangan optimis. Dalam Gotzamani dan Tsotras (2001) disebutkan bahwa menurut pandangan optimis, berdasarkan fakta, standar ISO 9000 memiliki alat yang terstruktur dengan baik. Standar ISO 9000 mengurangi gap antara lingkungan manajemen kualitas saat ini dengan TQM pada kebanykan perusahaan, mengubah focus dari produk akhir menjadi focus kepada proses, meningkatkan operasi dan organisasi internal, komunikasi organisasi menjadi lebih seragam dan efektif, meningkatkan kesadaran pekerja terhadap isu-isu kualitas, variasi kualitas menjadi lebih rendah, biaya kualitas lebih rendah, kepuasan konsumen meningkat, kepercayaan terhadap perusahaan meningkat, dan ketika ISO 9000 diimplementasikan akan meningkatkan komitmen dan tanggung jawab terhadap kualitas. Pandangan optimis juga menyatakan bahwa meskipun ISO 9000 dengan TQM ada perbedaan, namun implementasi ISO 9000 merupakan langkah awal menuju TQM.

Untuk menguji keterkaitan antara ISO 9000 dengan TQM, Gotzamani dan Tsiotras (2001) melakukan penelitian terhadap perusahaan-perusahaan di Yunani yang telah memperoleh sertifikasi ISO 9000. Mereka menggunakan indicator kinerja delapan elemen dasar TQM, yaitu: Leadership, Strategic Quality Planning, Quality Data, Human Resources Management, Process Management, Suppliers, Customers, dan Product Design. Hasil penelitian menunjukkan bahwa perusahaan-perusahaan tersebut memperoleh peningkatan kinerja TQM pada seluruh elemen dasar tersebut setelah menerapkan ISO 9000. Hasil penelitian tersebut memperkuat pendapat bahwa antara ISO 9000 dengan TQM memiliki keterkaitan erat, ISO 9000 sebagai basis penerapan TQM.

Dalam Magd dan Curry (2003), beberapa ahli kualitas lain yang berpandangan sama, misalnya Arora (1996) yang menggambarkan bahwa ISO 9000 sebagai pilar pendekatan terhadap TQM yang di dalamnya memuat elemen-elemen penting 
seperti pelatihan, Statistical Process Control (SPC), dan komitmen manajemen. ISO 9000 merupakan bagian penting dari TQM. Lai (1996) menyatakan bahwa TQM adalah pendekatan terhadap kualitas yang melebihi ISO 9000. Dia menambahkan bahwa ISO 9000 dan TQM bukan alternatif yang berbeda satu sama lain. ISO 9000 membangun pondasi yang kuat bagi lingkungan TQM, menekankan kebutuhan konsumen, keterlibatan pekerja, dan peningkatan kualitas yang kontinyu. McAdam dan Jackson (2002), Williams (1997), Askey dan Dale (1994) menyatakan bahwa sertifikasi ISO 9000 menyediakan bangunan kokoh bagi kesuksesan dan efektivitas penerapan TQM.

Hasil penelitian dan pandangan para ahli kualitas tersebut sangat jelas menerangkan bahwa antara ISO 9000 dengan TQM memiliki keterkaitan yang sangat erat. Bahkan bisa dikatakan jika ISO 9000 merupakan bagian dari TQM. Namun hasil penelitian dan pandangan tersebut tidak ada yang menyebutkan letak perbedaan atau kesenjangan (gap) antara ISO 9000 dengan TQM. Untuk mengetahui perbedaan ISO 9000 dengan TQM, Lim dan Niew (1995) menyodorkan perbandingan antara filosofi TQM dengan Standar Sistem Manajemen Kualitas ISO 9000 yang tersaji dalam tabel 4 .

Tabel 4. Perbandingan Filosofi TQM dengan ISO 9000

\begin{tabular}{|c|c|c|}
\hline \multicolumn{2}{|r|}{ Filosofi TQM } & $\begin{array}{r}\text { Filosofi ISO } 9000 \\
\end{array}$ \\
\hline$\square$ & $\begin{array}{l}\text { Fokus pada konsumen atau kepuasan kon- } \\
\text { sumen. }\end{array}$ & $\begin{array}{l}\text { Tidak memfokuskan pada konsumen atau } \\
\text { kepuasan konsumen. }\end{array}$ \\
\hline$\square$ & Menyatu dengan strategi perusahaan. & Tidak menyatu dengan strategi perusahaan. \\
\hline$\square$ & $\begin{array}{l}\text { Memusatkan perhatian pada filosofi, konsep, } \\
\text { alat, dan teknik. }\end{array}$ & $\begin{array}{l}\text { Memusatkan perhatian pada sistem dan } \\
\text { prosedur teknis. }\end{array}$ \\
\hline$\square$ & $\begin{array}{l}\text { Menekankan pemberdayaan dan keterli- } \\
\text { batan pekerja. }\end{array}$ & Tidak mementingkan keterlibatan pekerja. \\
\hline$\square$ & $\begin{array}{l}\text { Perbaikan secara terus menerus dan } \\
\text { berkesinambungan. }\end{array}$ & $\begin{array}{l}\text { Tidak memperhatikan perbaikan secara } \\
\text { terus menerus dan berkesinambungan. }\end{array}$ \\
\hline$\square$ & Mencakup seluruh level perusahaan. & Bisa meliputi satu departemen saja. \\
\hline$\square$ & $\begin{array}{l}\text { Setiap orang bertanggung jawab terhadap } \\
\text { terwujudnya kualitas. }\end{array}$ & $\begin{array}{l}\text { Penanggung jawab kualitas adalah departe- } \\
\text { men pengendali kualitas. }\end{array}$ \\
\hline$\square$ & $\begin{array}{l}\text { Merupakan proses keterlibatan semua pihak } \\
\text { dan perubahan budaya. }\end{array}$ & Status quo. \\
\hline
\end{tabular}
Sumber: Lim dan Niew (1995)

Berdasarkan perbandingan pada Tabel 4, tampak bahwa terdapat perbedaan esensial antara ISO 9000 dengan TQM. Secara umum cakupan dalam TQM jauh lebih luas dibanding cakupan ISO 9000. Pandangan Rao (1997) dalam Martinez-Lorente dan Matinez-Costa (2002) sejalan dengan hasil penelitian tersebut. Rao (1997) menyatakan bahwa perusahaan yang memperoleh sertifikasi ISO memiliki level TQM lebih tinggi dibanding perusahaan yang belum/tidak mendapatkan sertifikasi ISO. 
Berkaitan dengan ISO 9000 dan TQM, Martinez-Lorente dan MartinezCosta (2002) melakukan penelitian terhadap perusahaan-perusahaan di Spanyol untuk memperoleh kejelasan perbedaan antara implementasi ISO 9000 dengan TQM. Dalam tinjauan teorinya, mereka menyatakan bahwa perusahaan yang memperoleh sertifikasi ISO 9000 telah memperoleh bagian cara yang terdapat dalam TQM, yaitu: pengumpulan data dan informasi, manajemen aliran proses, dan penggunaan alat-alat statistik. Beberapa hal tersebut disebut sebagai bagian awal dari TQM. Mereka juga menyatakan bahwa sebagian besar persyaratan TQM belum dipenuhi ISO 9000, yaitu:

- Perbaikan terus menerus. ISO 9000 memperkenalkan perbaikan hanya pada level pencegahan koreksi terhadap hal-hal yang tidak sesuai. Hal ini merupakan focus yang dinilai pasif.

- Fokus pada konsumen. ISO 9000 hanya mensyaratkan aplikasi pada rangkaian prosedur spesifikasi disain, tetapi bukan pada usaha memperoleh kepuasan konsumen.

- Pengembangan dan partisipasi pekerja.

Di samping itu, beberapa elemen ISO 9000 berseberangan dengan TQM, misalnya:

- Excessive bureaucracy. Impementasi ISO 9000 sangat birokratis dengan prosedur yang formal dan bertele-tele, sedangkan TQM menekankan keterbukaan, keterlibatan dan partisipasi aktif pekerja.

- Lack of flexibility. Prosedur dalam ISO 9000 yang formal cenderung bersifat kaku dan seringkali tidak humanis.

- ISO 9000 memaksa perusahaan membuat pengendalian produk yang diterima dari pemasok, sedangkan TQM menekankan "relationship" antara perusahaan dengan pemasok atas dasar saling percaya.

Hasil penelitian Martinez-Lorente dan Martinez-Costa (2002) membuktikan bahwa implementasi TQM mampu meningkatkan kinerja operasi perusahaan, sedangkan implentasi ISO 9000 hubungannya dengan kinerja operasi perusahaan, tidak signifikan. Hal ini nerarti bahwa ISO 9000 tidak memberikan kontribusi terhadap peningkatan kinerja, ketika perusahaan telah mengimplementasikan TQM.

Mendasarkan pada hasil penelitian dan pandangan ahli kualitas, tidak berlebihan jika kemudian banyak pihak yang tidak puas terhadap standar ISO 9000: 1994. Revisi dilakukan agar standar ISO 9000 mengacu pada semangat total quality yang telah didengung-dengungkan cukup lama.

\section{ISO 9000: 2000 (REVISI TERHADAP ISO 9000:1994)}

ISO 9000 telah direvisi beberapa kali sejak dipublikasikan pertama kali tahun 1987. Revisi yang pertama dilakukan tahun 1994, kemudian tahun 1998, dan terakhir tahun 2000. ISO 9000: 2000 merupakan respon terhadap ketidakpuasan yang semakin meluas terhadap satandar lama. Standar baru memiliki struktur baru 
yang lebih lengkap yang didasarkan oleh delapan prinsip aturan-aturan dasar yang komperehensif atau nilai-nilai kepercayaan untuk kepemimpinan dan operasi organisasi yang merefleksikan prinsip-prinsip dasar total quality (Evans dan Davis, 2003; Cargill, 2001; Russell, 2000). Delapan prinsip tersebut adalah:

- Customer focus organization

Organisasi tergantung pada konsumen mereka, oleh karena itu organisasi harus memahami kebutuhan konsumen saat ini dan yang akan datang, harus memenuhi persyaratan yang ditentukan konsumen, dan berusaha memenuhi harapan konsumen.

- Leadership

Pemimpin harus menciptakan dan memelihara lingkungan internal sehingga orang-orang dalam organisasi terlibat aktif dalam pencapaian sasaran organisasi.

- Involvement of people

Orang-orang pada semua level merupakan hal yang esensial bagi organisasi. Keterlibatan aktif mereka secara penuh akan memberi manfaat bagi organisasi.

- Process approach

Hasil-hasil yang ditentukan akan tercapai secara lebih efisien jika aktivitas dan sumber daya yang berkaitan dikelola sebagai suatu proses.

- System approach to management Identifikasi, pemahaman, dan pengaturan proses-proses yang saling berkaitan sebagai sebuah system memberikan kontribusi terhadap efektivitas dan efisiensi organisasi dalam pencapaian sasaran.

a Continuous improvement

Perbaikan yang kontinyu terhadap kinerja organisasi secara menyeluruh harus menjadi sasaran obyektif organisasi.

- Factual approach to decision making Keputusan yang efektif didasarkan pada analisis data dan informasi.

- Mutually beneficial supplier relationship

Antara Organisasi dengan pemasok memiliki ketergantungan satu sama lain dan terjalin hubungan yang saling menguntungkan sehingga keduanya mampu menciptakan nilai.

Menurut Evans dan Davis (2003), ISO 9000: 2000 memiliki keeratan hubungan dengan semangat total quality, misalnya:

- Organisasi saat ini memerlukan proses untuk memenuhi kebutuhan dan harapan konsumen, menterjemahkan ke dalam persyaratan internal dan mengukur kepuasan maupun ketidakpuasan konsumen.

- Manajer harus mengkomunikasikan tingkat kepentingan konsumen dan persyaratan yang telah ditentukan, mengintegrasikan ISO 9000 ke dalam rencana bisnis, sasaran yang bisa diukur, dan melakukan tinjauan manajemen. 
- Organisasi saat ini harus memandang kerja sebagai suatu proses dan mengatur system proses yang berkaitan.

- Analisis saat ini harus dilakukan untuk menyediakan informasi tentang kepuasan dan ketidakpuasan konsumen, produk, dan proses dengan focus perbaikan.

- Efektivitas pelatihan harus dieveluasi dan individu dalam organisasi dibuat sadar terhadap pentingnya kesesuaian aktivitas mereka dengan sasaran konsumen.

- Jika pada standar ISO sebelumnya organisasi disyaratkan untuk melakukan tindakan koreksi dan pencegahan, saat ini organisasi harus memiliki proses perbaikan yang telah direncanakan.

ISO 9000 mengadopsi filosofi TQM dengan penekanan yang lebih kuat pada kepuasan konsumen dan orientasi pendekatan proses yang efektif dengan focus peningkatan kinerja yang kontinyu. Standar ISO 9000: 2000 memfokuskan pada pertanggungjawaban manajemen, sumber daya manajemen, pengukuran dan realisasi produk, analisis dan perbaikan. Empat area perubahan tersebut merupakan perubahan signifikan terhadap standar yang disebabkan oleh perubahan persyaratan manajemen kualitas. Empat area tersebut menggambarkan empat fase dari konsep dasar standar baru yang didasarkan prinsip-prinsip manajemen kualitas.

\section{STRUKTUR ISO 9000:2000}

\section{a ISO 9000}

Standar ISO 9000:2000 terdiri dari tiga dokumen, yaitu:

Dasar-dasar sistem manajemen kualitas dan kosa kata - mendefinsikan terminologi dan standar

\section{a ISO 9001}

Persyaratan sistem manajemen kualitas, digunakan untuk menilai pemenuhan persyaratan (konsolidasi bentuk ISO 9001/9002/9003/ ke dalam dokumen tunggal)

\section{口 ISO 9004}

Pedoman sistem manajemen kualitas untuk peningkatan kinerja - menyediakan pedoman perbaikan sistem manajemen yang kontinyu

ISO 9000 menyediakan definisi kata-kata kunci. ISO 9001 menyediakan rangkaian persyaratan minimum sistem manajemen kualitas dan diharapkan menunjukkan pemenuhan prinsip-prinsip kualitas yang diakui konsumen dan sertifikasi pihak ketiga. ISO 9004 memfokuskan peningkatan sistem manajemen kualitas dengan persyaratan minimum.

\section{SIMPULAN}

ISO 9000 didisain untuk memenuhi standardisasi system manajemen kualitas. Perusahaan yang ingin memperoleh pengakuan konsumen dan pihak ketiga bahwa perusahaan tersebut telah melaksanakan praktek-praktek manajemen kualitas yang baik, salah satu jalan yang harus ditempuh adalah memperoleh 
sertifikasi ISO 9000. Kenyataan yang menunjukkan bahwa perusahaan yang telah mengimplementasikan ISO 9000 dan memperoleh sertifikasi ISO 9000 mengalami peningkatan kinerja, mendorong perusahaan-perusahaan lain di dunia untuk melakukan hal yang sama. Hal ini bisa dilihat dari angka pertumbuhan perusahaan yang memperoleh sertifikasi ISO 9000. Di negara-negara maju seperti Jepang, USA, Kanada, Singapura, dan negara maju lain menunjukkan bahwa jumlah perusahaan yang memperoleh sertifikasi ISO 9000 meningkat secara fantastis. Hal ini mengindikasikan bahwa kesadaran terhadap implementasi dan sertifikasi ISO 9000 tertanam sangat kuat.

Implementasi ISO 9000 terbukti menghasilkan manfaat bagi perusahaan, baik manfaat internal maupun eksternal. Manfaat internal terbesar yang diperoleh adalah menguatnya kesadaran pekerja terhadap pentingnya manajemen kualitas dan praktek manajemen kualitas semakin baik. Sedangkan manfaat eksternal yang paling berharga adalah tercapainya kepuasan konsumen sebagai simbul pengakuan bahwa praktek-praktek manajemen kualitas perusahaan telah dinilai baik, bahkan sempurna. Meskipun demikian, implementasi ISO 9000 masih dihadapkan pada sejumlah hambatan. Hambatan terbesar selama implementasi ISO 9000 adalah kegagalan organisasi dalam mendefinisikan tenggung jawab dan wewenang individu/personal, sedangkan hambatan terbesar setelah memperoleh sertifikasi ISO 9000 adalah kegagalan organisasi membawa tinjauan manajemen terhadap system kualitas untuk mencapai efektivitas sistem.

Implementasi ISO 9000 juga sering dikaitkan dengan TQM. Namun antara ISO 9000 dengan TQM memiliki perbedaan prinsip dalam beberapa elemen dasar. Oleh karena itu revisi terhadap ISO 9000 selalu dilakukan dengan mengacu pada pendekatan TQM secara menyeluruh.

\section{DAFTAR PUSTAKA}

Anderson, S.W., Daly, J.D. and Johnson, M.F. (1999),'Why firms seek ISO certification: regulatory compliance or competitive advantage?", Production and Operations Management Journal, Vol. 8 No. 9.

Arora, S.C. (1996), Applying ISO 9000 Quality Management Sytems, Trade Support Services Series, International Trade Centre, Geneva.

Askey, J.M. and Dale, B.G. (1994),"From ISO 9000 series registration to total quality management: an examination", Quality Management Journal, July.

Cargill, G. (2001),"Understanding the new ISO standars", Ceramic Industry, Vol. 151 No. 1.

Chatab, N. (1996), Panduan Penerapan dan Sertifikasi Sistem Manajemen Mutu ISO 9000. Jakarta: Gramedia. 
Chow-Chua, Clare. Goh, Mark, and Wan, Tan Boon. (2003),"Does ISO 9000 certification improve business performance?", The International Journal of Quality \& Reliability Management", Vo. 20 No. 8.

Evans, J.R. and Dean, Jr. James W. (2003), Total Quality: Management, Organization, and Strategy, Thomson South-Western, $3^{\text {rd }}$ ed.

Gotzamani, K.D. and Tsiotras, G.D. (2001),"An empirical study of the ISO 9000 standards'contribution toward total quality management", International Journal of Quality and Reliability Management, Vol. 21 No. 10.

Haversjo, T. (2000),"The financial effects of ISO 9000 certification for Danish companies", Managerial Auditing Journal, Vol. 15 No. 1.

Ho, S.K.M. (1999), "Change for the better via ISO 9000 and TQM", Management Decision, Vol. 37 No. 4.

Kantner, B. (1997), QS 9000 - Answer Book, Wiley, New York, NY.

Lai, H. (1996), ISO 9000 Quality Management Systems: Guidelines for Enterprises in Developing Countries, $2^{\text {nd }}$ ed., International Trade Centre and ISO, Geneva.

Larsen, B. and Haversjo, T. (2000),"The year 2000 problem of ISO 9000: will the quality standards survive the proposed year 2000 version?", The TQM Magazine, Vol. 12 No. 4.

Lim, T.E. and Niew, B.C. (1995), Quality Management System, Assesment to ISO 9000: 1994 series. Singapore: Prentice Hall.

Magd, Hesham, and Curry, Adrienne. (2003),"ISO 9000 and TQM: are they complementary or contradictory to each other?", The TQM magazine, Vol. 15 Number 4.

Martinez-Lorente and Martinez-Costa. (2002),"ISO 9000 and TQM: substitutes or complementaries? An empirical study in industrial companies", International Journal of Quality \& Reliability Management, Vol. 21 №. 3.

Quazi, A.H., Hong, W.C. and Meng, T.C. (2002),"Impacts of ISO 9000 certification on quality management practices: a comparative study", Total Quality Management, Vol. 13 No. 1.

Rahman, S. (2001),"A comparative study of TQM practice and organizational performance of SMEs with and without ISO 9000 certification," International Journal of Quality \& Reliability management, Vol. 18 No.1.

Russell, S. (2000),"ISO 9000: 2000 and the EFQM excellence model: competition or co-operation:, Total Quality Management, Vol. 13 No. 1. 
Singels, J., Ruel, G. and Van der water, H. (2001),"ISO 9000 series: certification and performance", International Journal of Quality \& Reliability Management, Vol. 18 No. 1.

Stevenson, H.T. and Barnes, C.F. (2001),"Fourteen years of ISO 9000: impact, cricism, costs, and benefits", Business Horizons, May-June.

Sun, H. (2000),"Total Quality management, ISO 9000 certification and performance improvement", International Journal of Quality \& Reliability Management, Vol. 17 No. 2.

William, N. (1997),"ISO 9000 as a route to TQM in small to medium size enterprise: snake or ladder?", The TQM Magazine, Vol. 9 No.1. 